\title{
PSYCHOMETRIC PROPERTIES OF THE ANOMIA QUESTIONNAIRE (AQ)
}

\author{
Jeḷena Levina \\ Kristīne Mārtinsone \\ Rīga Stradiņš University, Latvia
}

\begin{abstract}
The purpose of this research was to develop the Anomia Questionnaire (AQ), which measures different dimensions of anomia and is based on the Levina, Martinsone, and Kamerade (Levina, Mārtinsone, \& Kamerāde, 2015c, 2016a) integrative multidimensional model of anomia, as well as to determine its psychometric properties. The $A Q$ was developed in Latvian. The sample consisted of 210 Latvian inhabitants aged from 19 to 58 years $(27.6 \%$ male, $72.4 \%$ female). The factorial validity of the $A Q$ was established using principal components analysis with Varimax rotation; this yielded six factors, which can be interpreted as Social Distrust (C1), Lack of Goal Clarity (C2), Generalized Sense of Meaninglessness (C3), Cultural Isolation (C4), Deviation from Prescribed Rules or Customs (C5), and Estrangement to Others (C6). All the AQ scales had high internal consistency (Cronbach's alpha varied from .73 to .86). The reaction and discrimination indices satisfied the accepted psychometric criteria.

The further stage of the $A Q$ development would be the confirmatory factor analysis in broader international sample, the concurrent and convergent validity establishing, and test-retest reliability examination.
\end{abstract}

Keywords: anomia, deviation from prescribed rules and customs, social distrust, estrangement to others, cultural isolation, lack of goal clarity, generalized sense of meaninglessness, factorial validity, reliability.

\section{Introduction}

Research of anomia is actual in the period when the society endures social and economic changes. Social, economic, political, cultural changes at the level of society cause anomie - the condition or state, in which there is a breakdown of social norms and guidance for the citizens of a society (Durkheim, [1893] 1964), as well the discrepancy between common social goals and the legitimate means to attain those goals (Merton, 1964). At the individual level such changes cause anomia - "subjectively perceived anomie" (Lytkina, 2012). Thus, anomia can serve as an indicator of political, legislative, economic and other changes of the society (L,evina, Mārtinsone, \& Kamerāde, 2015a). 
In some recent research (e.g., Levina, Martinsone, Kamerade, 2015) it was found that certain dimensions of anomia - social distrust, social isolation and meaninglessness - are negatively associated with such components of subjective well-being as overall life satisfaction and satisfaction with different life domains, as well as with general sense of happiness. Anomia is an important factor that predicts subjective well-being (L,evina, Mārtinsone, in press; Levina, Martinsone, Kamerade, 2015).

During three last decades Latvia has endured rapid social, economic, political, cultural changes, namely, the restoration of independence, the economic blossoming and the economic crisis, joining the European Union, joining NATO, the introduction of the euro, such changes in the labour market as a relatively high unemployment, labour migration. On the other hand bright changes occur in the modern world, such as wars, acts of terrorism, waves of refugees and others.

All these transitions in the development of the society could affect individuals and cause anomia and as a consequense, psychologial health as well as well-being and quality of life in general.

In the light of such facts research of anomia can be viewed as topical. Especially important is a question, how it is possibble to measure anomia at the individual level.

Thus, the main purpose of this research is to clarify the concept of anomia and to introduce the newly developed instrument for measurement of anomia, namely, the Anomia Questionnaire.

\section{The notion of anomia: Anomia as a multidimensional concept}

Different scientists recognize and describe separate aspects of anomie/ anomia. In the recent research of a model of anomia in the Baltic states a review of previous theories of anomie/anomia was conducted (L,evina, Mārtinsone, \& Kamerāde, 2016a). It has been shown, that, according to Émile Durkheim (Durkheim, [1897] 1951), when the society is in the state of a breakdown of social norms and guidance, an individual can feel that he or she is not integrated into the greater whole society and can experience the meaninglessness that even can lead to anomic suicide. Using the term "anomy" Robert MacIver (MacIver, 1950) emphasized such an aspect of anomy as a breakdown of an individual's sense of attachment to society. Leo Srole (Srole, 1956) accented such an aspect of anomia as "self-to-others alienation". According to Melvin Seeman (Seeman, 1959) anomie referred to normlessness. Dwight Dean (Dean, 1961) considered that there were two components of anomie - normlessness and social isolation. Dean also assumed that there existed two subtypes of normlessness, namely, purposelessness and conflict of norms. 
Thus, it is possible to summarize that characterizing separate certain dimension of anomie/anomia different theorists paid attention to different components of anomie/anomia. Nevertheless, three main components of anomia are described consistently in the scientific literature that can be defined as normlessness, social isolation and meaninglessness. Moreover, resent research in which reviews of previous theories and investigations of anomie/anomia were made (e.g., Levina, Martinsone, 2015; Levina, Martinsone, Kolesnikova, \& Perepjolkina, 2014; L,evina, Mārtinsone, \& Kamerāde, 2015c, 2016b), primarily, in above mentioned review (Levina, Martinsone, \& Kamerade, 2016a), allows to conclude that each major component of anomia includes some certain subdimensions ${ }^{1}$.

Also empirical studies, in which questionnaires and secondary data from the European Quality of Life Survey (European Quality of Life Survey (EQLS), 2012) (L,evina, Mārtinsone, \& Kamerāde, 2015b, c, 2016a) and from the European Values Study (European Values Study (EVS), 2008) (Ļevina, Mārtinsone, \& Klince, 2016) were used, have confirmed that anomia is multidimensional.

On the base of above mentioned conclusions and findings the integrative multidimensional model was proposed and gradually developed by Levina, Mārtinsone and co-authors (Levina, Martinsone, Kolesnikova, \& Perepjolkina, 2014; Levina \& Martinsone, 2015; L̦evina, Mārtinsone, \& Kamerāde, 2015b, c, 2016a). According to this model anomia is defined as an individually psychological state when the person beliefs that there are no social norms, rules and prescriptions, which can regulate his / her own behavior as well as the behavior of other citizens of the society, when the person endures the psychological state of social isolation and meaninglessness. Anomia is multidimensional and includes three main dimensions normlessness, social isolation, and meaninglessness. Each major dimension of anomia is divided into two sub-dimensions. Normlessness as a perceived breakdown of the social order in which norms no longer regulate behavior includes an individual's deviation from prescribed rules or customs and social distrust. Social isolation as a loss of a sense of community includes estrangement to others and cultural isolation. At last, meaninglessness as an absence or unclarity of terminal goals (life meanings) as prescriptions for an individual's behavior includes the lack of goal clarity and generalized sense of meaninglessness.

\footnotetext{
${ }^{1}$ For a full review see L̦evina, J., Mārtinsone, K., \& Kamerāde, D. (2016). A Model of Anomia in the Baltic States. The International Journal of Interdisciplinary Civic and Political Studies, 11 (3), pp.112.
} 


\section{Questionnaire development}

Despite of that fact that anomia is confirmed and recognized as multidimensional, there is a lack of available instruments, which measure different multiple dimensions of anomia.

The existing situation can be characterized as follows. First, most instruments that measures anomia, are unidimensional. As examples of such instruments Srole's Anomia Scale (Srole, 1956) or McClosky's and Schaar's Anomy Scale (McClosky \& Schaar, 1965) can be mentioned. Second, those studies, in which multiple indices of anomia were measured, are conducted using secondary data (e.g., Levina, Martinsone, Kamerade, 2015; L,evina, Mārtinsone, in press; L̨evina, Mārtinsone, Kamerāde, 2015b, c; 2016a, b; L̨evina, Mārtinsone, \& Klince, 2016).

Thus, the purpose of this study was to develop a new multidimensional questionnaire that can be used to measure different dimensions of anomia and to determine its psychometric properties.

A review of the scientific literature, that was conducted earlier (Levina, Martinsone, \& Kamerade, 2016) and as it was already mentioned above and was shown, that it is possible to distinguish between six sub-dimensions of anomia, namely, (1) individual's deviation from prescribed rules or customs, (2) social distrust, (3) estrangement to others, (4) cultural isolation, (5) the lack of goal clarity, (6) generalized sense of meaninglessness. The initial item pool was developed based on this theoretical basis.

A pool of 136 initial items was constructed. The initial items were refined and edited for content validity by two academic faculty member. An expert judgement is a general technique of item generation (DeVellis, 2003; Netemeyer, Bearden, \& Sharma, 2003).

In the empirical study the items that have appropriate reaction and discrimination indices will be selected. The factorial validity will be established. Based on principal component analysis the scales will be determined. The internal concistency of scales will be cheked (Kline, 2000).

The research question is: Do psychometric properties of the AQ satisfy reliability and validity criteria of psychometrics?

\section{Method}

\section{Participants}

The Latvian sample consisted of the inhabitants of Latvia $(n=210)$, aged from 19 to 58 years $(27.6 \%$ male, $72.4 \%$ female $)$.

The largest part of respondents live in Riga or near Riga (109 persons), 23 respondents live in another large city, 48 respondents live in a small town, 19 
respondents - in a village, while 11 respondents indicated that they live a village house.

The largest part of respondents (185 persons) indicated that their mother tongue is Latvian, and 25 respondents has a mother tongue Russian. The largest part of respondents (188 persons) were Latvian, 15 respondents were Russian, 3 respondents were Belarusian. Other respondents indicated other nationalities.

Regarding education level, 29 respondents have secondary education, 27 respondents have special secondary education or vocational secondary education, the largest part of respondents -68 persons have unfinished higher education, 13 respondents have a higher education (I level) and 43 respondents have a higher education (II level, bachelor's degree), 29 respondents have a master's degree and 1 respondent has $\mathrm{PhD}$.

At the moment of participation in the research 1 respondent was getting a higher education (I level), the largest part of respondents ( 89 persons) were getting a higher education (II level, bachelor's degree), 25 respondents - were studying a master's programme, and 2 respondents - a doctoral programme. At the same time only 14 respondents indicated that they are not students, while 79 persons didn't answer this question because they also are not students and work or are unemployed.

More often these respondents work in the area of health/ social care ( 8 respondents), education/ sciences ( 8 respondents), service industry (7 respondents), commerce ( 7 respondents), factory production (6 respondents), transport/ logistics (6 respondents) and construction industry (6 respondents). In other areas there work less than 5 respondents.

\section{Instrument}

Anomia Questionnaire (AQ). The initial item pool consisted of 136 items, however, based on the results of the psychometric analysis, the number of items was reduced to 24 . Responses are made on a 5-point Likert scale (from 1-strongly disagree to 5-strongly agree). The questionnaire is in Latvian.

Items examples are provided lower:

- "I always try to act in accordance with the law" (a_q_22_dprc) - scale Deviation from Prescribed Rules and Customs;

- "I trust the Government" (a_q_103_sd) - scale Social Distrust;

- "Other people do not care about me" (a_q_48_eo) - scale Estrangement to Others;

- $\quad$ "It seems to me that my values are different from surrounding people's values" (a_q_104_ci) - scale Cultural Isolation;

- "I know exactly what I would like to achieve in life" (a_q_17_lgc) scale Lack of Goal Clarity; 
- "Taking into account the current situation, I find it hard to look into the future with hope" (a_q_89_gsm) - scale General Sense of Meaninglessness.

\section{Procedure}

Data were collected on a voluntary basis via internet from January 2016 to May 2016. All participants filled out the test on-line.

\section{Results}

The newly established the AQ consists of 24 items that form six sales: Social Distrust $(k=4)$, Lack of Goal Clarity $(k=4)$, Generalized Sense of Meaninglessness $(k=4)$, Cultural Isolation $(k=4)$, Deviation from Prescribed Rules or Customs $(k=4)$, Estrangement to Others $(k=4)$.

\section{Descriptive statistics and reliability}

Cronbach's alpha coefficients for all scales of the AQ were computed. Cronbach's alpha varied from .73 to .86 ), so that it could be said that reliability for all scales was acceptably high (see Table 1).

Table 1 Descriptive statistics and reliability indices for the AQ

\begin{tabular}{lcccc}
\hline Scales of AQ & $\begin{array}{c}\text { Number of } \\
\text { items }\end{array}$ & $\begin{array}{c}\text { Cronbach's } \\
\text { alpha }\end{array}$ & Mean & SD \\
\hline Social Distrust & 4 & .84 & 15.76 & 3.24 \\
Lack of Goal Clarity & 4 & .84 & 8.10 & 3.57 \\
Generalized Sense of Meaninglessness & 4 & .86 & 9.58 & 3.90 \\
Cultural Isolation & 4 & .73 & 11.16 & 3.23 \\
Deviation from Prescribed Rules or Customs & 4 & .74 & 8.84 & 3.04 \\
Estrangement to Others & 4 & .78 & 8.36 & 3.47 \\
\hline
\end{tabular}

Items reaction and discrimination indices satisfied the psychometric criteria (see Table 2).

Items of the AQ showed good reaction indices with one exception, namely, pant a_q_13_lgc that has a decreased reaction index. This pant sounded "There are no specific goals in my live to achieve". Probably, such a decreased reaction index can be explained by the specific sample - the largest part of this sample consisted of students. Therefore, it is possible to assume that they have specific goals in their live to achieve. 
Table 2 Item statistics by scale for the AQ

\begin{tabular}{|c|c|c|c|c|c|c|c|c|c|c|c|}
\hline Item & $M$ & $S D$ & $\begin{array}{c}\text { Correted } \\
\text { Item-T otal } \\
\text { Correlation } \\
\end{array}$ & Item & $M$ & $S D$ & $\begin{array}{c}\text { Correted } \\
\text { Item-Total } \\
\text { Correlation } \\
\end{array}$ & Item & $M$ & $S D$ & $\begin{array}{c}\text { Correted } \\
\text { Item-Total } \\
\text { Correlation }\end{array}$ \\
\hline \multicolumn{4}{|c|}{ Social Distrust } & \multicolumn{4}{|c|}{ Lack of Goal Clarity } & \multicolumn{4}{|c|}{ Generalized Sense of Meaninglessness } \\
\hline a_q_103_sd & 4.09 & .92 & .77 & a_q_77_lgc & 2.26 & 1.09 & .72 & a_q_89_gsm & 2.36 & 1.21 & .78 \\
\hline a_q_93_sd & 4.09 & .89 & .73 & a_q_126_1gc & 1.97 & .98 & .74 & a_q_119_gs & 2.49 & 1.24 & .72 \\
\hline a_q $55 \_s d$ & 3.89 & .99 & .59 & a_q_13_lgc & 1.71 & 1.00 & .65 & a_q_49_gsm & 2.77 & 1.12 & .66 \\
\hline a_q_114_sd & 3.69 & 1.12 & .66 & a_q_9_1gc & 2.16 & 1.28 & .59 & a_q_65_gsm & 1.96 & 1.03 & .70 \\
\hline Scale mean & 3.94 & & & Scale mean & 2.02 & & & Scale mean & 2.39 & & \\
\hline \multicolumn{4}{|c|}{ Cultural Isolation } & \multicolumn{4}{|c|}{ Deviation from Prescribed Rules or Customs } & \multicolumn{4}{|c|}{ Estrangement to Others } \\
\hline a_q_104_ci & 2.68 & 1.06 & .67 & a_q_22_dprc & 2.36 & 1.07 & .60 & a_q_48_eo & 2.20 & 1.21 & .52 \\
\hline a_q1125_ci & 2.65 & 1.11 & .62 & a_q_6_dprc & 2.25 & 1.02 & .61 & a_q_44_eo & 2.21 & 1.27 & .64 \\
\hline a_q_81_ci & 2.94 & 1.07 & .48 & a_q_1_dprc & 1.90 & 1.02 & .42 & a_q_118_eo & 2.08 & .94 & .62 \\
\hline a_q_72_ci & 2.89 & 1.10 & .33 & a_q_38_dprc & 2.32 & .95 & .49 & a_q_124_eo & 1.87 & 1.01 & .62 \\
\hline Scale mean & 2.79 & & & Scale mean & 2.21 & & & Scale mean & 2.09 & & \\
\hline
\end{tabular}

Note: a_q_x - anomia question and number from the initial pool (initial questionnaire);

sd - questions that were constructed to measure social distrust;

ci - questions that were constructed to measure cultural isolation;

$\operatorname{lgc}$ - questions that were constructed to measure lack of goal clarity;

dprc - questions that were constructed to measure deviation from prescribed rules and customs;

gsm - questions that were constructed to measure general sense of meaninglessness;

eo - questions that were constructed to measure estrangement to others.

The average reaction index was 2.57. Coefficients of correlations between each item and the sum of the remaining items in the scale ranged from .33 to .78 , and in most cases were moderately high or high.

\section{Factorial validity}

Six factors of the AQ are yielded using principal component analysis with Varimax rotation. The KMO measure was .78, and the Bartlett test was significant $\chi^{2}(120)=1224.94(p=.00)$.

The component analysis of the selected items supported the factors the AQ was designed to measure.

All components had high loadings for items from equivalent the AQ dimensions and could be identified as Social Distrust (C1), Lack of Goal Clarity (C2), Generalized Sense of Meaninglessness (C3), Cultural Isolation (C4), Deviation from Prescribed Rules or Customs (C5), and Estrangement to Others (C6). 
Table 3 Results of Principal Component Analysis with a Varimax Rotation for the AQ

\begin{tabular}{|c|c|c|c|c|c|c|c|}
\hline \multirow[b]{3}{*}{ Anomia's dimensions and variables } & \multicolumn{7}{|c|}{ Component Loadings } \\
\hline & \multirow{2}{*}{$\begin{array}{l}C 1 \\
\text { before } \\
\text { rotation }\end{array}$} & C1 & $C 2$ & \multirow{2}{*}{\multicolumn{2}{|c|}{$\begin{array}{l}\text { C3 } \quad \text { C4 } \\
\text { after rotation }\end{array}$}} & \multirow[t]{2}{*}{$\mathrm{C5}$} & C6 \\
\hline & & & & & & & \\
\hline \multicolumn{8}{|l|}{ Social Distrust } \\
\hline a_q_103_sd & .70 & .85 & -.07 & .26 & -.02 & .03 & -.04 \\
\hline a_q_93_sd & .69 & .83 & .00 & .22 & .07 & .05 & -.02 \\
\hline a_q_55_sd & .68 & .74 & -.03 & -.03 & -.03 & .16 & .28 \\
\hline a_q_114_sd & .67 & .73 & .00 & .22 & .06 & .24 & .04 \\
\hline \multicolumn{8}{|l|}{ Lack of Goal Clarity } \\
\hline a_q_77_lgc & .67 & .06 & .87 & .06 & -.06 & .02 & .12 \\
\hline a_q_126_lgc & .66 & .00 & .85 & .17 & .01 & .06 & .12 \\
\hline a_q_13_lgc & .62 & -.17 & .78 & .15 & .15 & .08 & -.01 \\
\hline a_q_9_lgc & .60 & .02 & .66 & .17 & .13 & .14 & .31 \\
\hline \multicolumn{8}{|l|}{ Generalized Sense of Meaninglessness } \\
\hline a_q_89_gsm & .55 & .11 & .14 & .82 & .11 & .06 & .22 \\
\hline a_q_119_gsm & .53 & .21 & .10 & .79 & .21 & .05 & .18 \\
\hline a_q_49_gsm & .38 & .24 & .29 & .68 & .02 & -.17 & .18 \\
\hline a_q_65_gsm & .43 & .21 & .21 & .68 & -.05 & -.03 & .37 \\
\hline \multicolumn{8}{|l|}{ Cultural Isolation } \\
\hline a_q_104_ci & .47 & -.03 & .07 & .09 & .85 & -.01 & .12 \\
\hline a_q_125_ci & .39 & .03 & .03 & .08 & .77 & .02 & .28 \\
\hline a_q_81_ci & .42 & -.03 & -.04 & .15 & .70 & .37 & .06 \\
\hline a_q_72_ci & .20 & .36 & .23 & -.21 & .50 & -.16 & .12 \\
\hline \multicolumn{8}{|c|}{ Deviation from Prescribed Rules or Customs } \\
\hline a_q_22_dprc & .27 & .04 & .10 & -0.02 & .00 & .80 & -.02 \\
\hline a_q_6_dprc & .31 & .21 & .08 & -0.05 & .05 & .76 & .01 \\
\hline a_q_1_dprc & .41 & -.03 & .00 & 0.14 & -.02 & .68 & .05 \\
\hline a_q_38_dprc & .22 & .21 & .08 & -0.14 & .16 & .65 & .14 \\
\hline \multicolumn{8}{|l|}{ Estrangement to Others } \\
\hline a_q_48_eo & .47 & .09 & .05 & .25 & -.02 & .02 & .74 \\
\hline a_q_44_eo & .44 & .06 & .17 & .25 & .30 & -.02 & .68 \\
\hline a_q_118_eo & .50 & .08 & .30 & .12 & .30 & .14 & .67 \\
\hline a_q_124_eo & .33 & .01 & .14 & .25 & .39 & .09 & .61 \\
\hline Eigenvalues & & 2.930 & 2.890 & 2.800 & 2.530 & 2.450 & 2.420 \\
\hline$\%$ of variance & & 12.200 & 12.030 & 11.650 & 10.550 & 10.190 & 10.090 \\
\hline
\end{tabular}

\section{Discussion}

This study investigated the reliability and the factorial structure of the Anomia Questionnaire (AQ). The inner structure of the developed AQ is characterized by a clearly interpretable six-factor structure. The obtained factors can be interpreted as Social Distrust, Lack of Goal Clarity, Generalized Sense of Meaninglessness, Cultural Isolation, Deviation from Prescribed Rules or Customs, and Estrangement to Others.

Two factors (Social Distrust and Deviation from Prescribed Rules or Customs) can be categorized as such dimension of anomia as normlessness. Two 
factors (Estrangement to Others and Cultural Isolation) were categorized as social isolation. At last, two factors (Lack of Goal Clarity and Generalized Sense of Meaninglessness) can be categorized as meaninglessness.

In general, the results of the present study, namely, the revealed interpretable factors and their further categorization as three main aspects of anomia are consistent with other researchers' findings. In spite of the fact, that other researchers used various terms in order to define certain components of anomia, in general, they demonstrated that normlessness (e.g., Durkheim, [1893] 1964; Seeman, 1959; Dean, 1961), social isolation (e.g., Durkheim, [1893] 1964; MacIver, 1950; Srole, 1956; Dean, 1961) and meaninglessness (e.g., Durkheim, [1893] 1964; Dean, 1961) are major dimensions of anomia.

It is important to mention, that each sub-dimension of anomia that was included into the integrative multidimensional model of anomia, developed by Ḷevina, Mārtinsone and co-authors (Levina, Martinsone, Kolesnikova, \& Perepjolkina, 2014; Levina \& Martinsone, 2015; L,evina, Mārtinsone, \& Kamerāde, 2015b, c, 2016a) and served as a theoretical base for the construction of a certain scale of the Anomia Questionnaire, has its main signs.

Thus, deviation from prescribed rules or customs has such main signs as the lack of an individuals' respect of presumed norms and readiness to engage in particular acts of deviance and to use non-normative means in order to attain desirable goals. Social distrust has such main signs as the lack of trustworthiness to government and other social institutions as well as the lack of trustworthiness to other people (doubts that others are generally fair, honest and respect presumed norms).

Main signs of estrangement to others are the lack of social support, the sense of loneliness, the sense of alienation, the sense of inferiority. In its turn, the sense of loss of internalized social norms and values are signs of cultural isolation.

At last, being without desirable and sensible goals are main signs of the lack of goal clarity, while generalized sense of meaninglessness has such signs as the sense of the lack of control and freedom, the sense of boredom, pessimism.

In this study the psychometric properties of the AQ confirm that it is a reliable instrument for its use. The study showed that internal consistency of the AQ was satisfactory. The further stage of the AQ development would be the confirmatory factor analysis in a broader international sample, the concurrent and convergent validity establishing, and test-retest reliability examination. Taking into account that the AQ was developed in Latvia in future it will be also valuable to adapt the test into other languages to make it appropriate for use by inhabitants of other countries of Europe and world. 


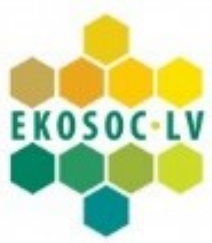

\author{
The paper was supported by the National Research Program 5.2. \\ "Economic Transformation, Smart Growth, Governance and Legal \\ Framework for the State and Society for Sustainable Development - a New \\ Approach to the Creation of a Sustainable Learning Community \\ (EKOSOC-LV)"
}

\title{
References
}

Dean, D. (1961). Alienation: Its meaning and measurement. American Sociological Review, 26 (5), 753-758.

DeVellis, R. F. (2003). Scale development: Theory and applications. London: Sage Publications.

Durkheim, É. ([1897] 1951). Suicide: A Study in Sociology. London, England: Routledge.

European Quality of Life Survey (EQLS). (2012). Downloaded from http://eurofound.europa.eu/surveys/eqls (Accessed 20 May 2015).

European Values Study (EVS). (2008). Downloaded from http://www.europeanvaluesstudy.eu/ page/survey-2008.html (Accessed 10 January 2016)

Levina, J., \& Martinsone, K. (2015). A revised integrative hierarchical model of anomia: Towards the construction of anomia indices. The 14th European Congress of Psychology "Linking technology and psychology: feeding the mind, energy for life" (Milan, Italy 710 July 2015): Abstract book (p. 2250). Downloaded from http://www.ecp2015.it/wpcontent/uploads/2015/07/ECP-2015-Abstract-Book_upd27jul1.pdf (Accessed 31 July 2015).

Levina, J., Martinsone, K., \& Kamerade, D. (2015). Anomia as a factor predicting subjective well-being. Med. psihol. Ross, 3 (32), 3. Iegūts no: http://www.mprj.ru/archiv_ global/2015_3_32/nomer07.php

Levina, J., Martinsone, K., Kolesnikova, J., \& Perepjolkina, V. (2014). Possibilities of research of anomie in Latvian society. In Vētra, A., \& Vilks, A. (Eds.) 5th International Interdisciplinary Scientific Conference ,, Society. Health. Welfare”. 2nd Conference of Speech Therapists (Rìga, November 26-28, 2014): Abstracts (p. 39). Rīga: RSU.

Levina, J., Mārtinsone, K., \& Kamerāde, K. (2015, a). Individuālā anomija kā sabiedrības politisko, tiesisko, ekonomisko pārmaiṇu indikators: tās psiholoǵiskās sekas. Starptautiskā zinātniskā konference "Drošības nostiprināšanas aktuālās problēmas: politiskie, sociālie, tiesiskie aspekti" (Rīgà 2015. gada 23. aprīlī). Programma un tēzes. International Scientific Conference "Topical Problems of Security Reinforcement: Political, Social, Legal Aspects” (Riga, April 23, 2015): Programme and Abstracts. Riga: RSU, 94.-96. lpp.

Ļevina, J., Mārtinsone, K., \& Kamerāde, D. (2015, b). Individuālās anomijas modeḷi Latvijas populācijā. Rìgas Stradina universitāte. 2015. gada zinātniskā konference: Tēzes (375. lpp.). Rīga: RSU.

Levina, J., Mārtinsone, K., \& Kamerāde, D. (2015, c). Sex and Age Differences in Levels of Anomia of Latvian Inhabitants. SOCIETY. INTEGRATION. EDUCATION. Proceedings of the International Scientific Conference, Vol. 3 (pp. 567-576). Rēzekne: RA izdevniecība. doi: 10.17770/sie2015vol3.475.

L,evina, J, \& Mārtinsone, K. (in press). Anomia, social participation and subjective well-being: A psychological perspective. 
L,evina, J., Mārtinsone, K., \& Kamerāde, D. (2016, a). A Model of Anomia in the Baltic States. The International Journal of Interdisciplinary Civic and Political Studies, 11 (3), 1 - 12. doi:10.18848/2327-0047/CGP.

L,evina, J., Mārtinsone, K., \& Kamerāde, D. (2016, b). The relationship between anomia and participation of Latvian inhabitants in social activities. International Interdisciplinary Scientific Conference "Society. Health. Welfare." Proceedings.

Levina, J., Mārtinsone, K., \& Klince, K. (2016). Relations between anomia and values of the inhabitants of the Baltic states. SOCIETY. INTEGRATION. EDUCATION. Proceedings of the International Scientific Conference, Vol. 1 (pp. 431-446). Rēzekne: RA izdevniecība. doi:10.17770/sie2016vol1.1518.

Lytkina, E. (2012). From anomie to alienation: An approach towards the measurement of social well-being and deviance. Papers of the IV Russian Sociology Congress. Moscow: Institute of Sociology RAN, Russian Sociological Society, 8227- 8231.

Kline, P. (2000). The handbook of psychological testing (2nd ed.). London: Routledge.

Maclver, R. M. (1950). The ramparts we guard. New York: Macmillan.

McClosky, H., \& Schaar, J. H. (1965). Psychological Dimensions of Anomy. American Sociological Review 30 (1): 14-40.

Merton, R. K. (1964). Anomie, Anomia, and Social Interaction: Contexts of Deviant Behavior. In M. B. Clinard (Ed.) Anomie and Deviant Behavior: A Discussion and Critique (pp. 213-242). NY: Free Press.

Netemeyer, R. G., Bearden, W. O., \& Sharma, S. (2003). Scaling procedures: Issues and applications. London: Sage Publications.

Seeman, M. (1959). On the meaning of alienation. American Sociological Review, 24 (6), $783-$ 791.

Srole, L. (1956). Social Integration and Certain Corollaries: An Exploratory Study. American Sociological Review 21 (6), 709-716. 